on. An oxygen tent costs a lot less than a heavy particle generator. More clinical trials are needed.

1 Schwarz, G., Münchener medizinische Wochenschrift, 1909, 56, 1217.

2 Gray, L H., et al., British fournal of Radiology, 1953, 26, 638.

3 Thomlinson, R. A., and Gray, L. H., British fournal of Cancer, 1955, 9, 539.

4 Van Putten, L. M., and Kallman, R. F., Fournal of the National Cancer Institute, 1968, 40, 441

5 Hewitt, H. B., Chan, D. P. S., and Blake, E. R., International fournal of Radiation Biology and Related Studies in Physics, Chemistry and Medicine, 1967, 12, 535.

6 Johnson, R. J. R., and Walton, R. J., American fournal of Roentgenology, Radium Therapy, and Nuclear Medicine, 1974, 120, 111

7 Churchill-Davidson, I., et al., British fournal of Radiology, 1966, 39, 321.

8 Churchill-Davidson, I., Sanger, C., and Thomlinson, R. H., Lancet, 1955,

1, 1091. Emery, E. W., British fournal of Radiology, 1964, 37, 722.

10 Emery, E. W., British Fournal of Radiology, 1964, 37, 722. Halnan, p. 309. London, Churchill Livingstone, 1972.

Halnan, p. 309. London, Churchill Livingstone,
1 Duncan, W., British Medical Bulletin, 1973, 29, 33.

12 Wildermuth, O., Radiologic Clinics of North America, 1969, 7, 345.

3 Van Den Brenk, H. A. S., Richter, W., and Hurley, R. H., British fournal of Radiology, 1968, 41, 205.

14 Henk, J. M., ot al., Clinical Radiology, 1970, 21, 223.

5 Alper, T. L., in Modern Trends in Radiotherapy, ed. T. J. Dealey and C. A. P. Wood, p. 1. London, Butterworths, 1967. 16 Plenk, H. P., American Fournal of Roentgenology, Radium Therapy, and

17 Dische, S., British fournal of Radiology, 1974, 47, 99.

18 Catterall, M., and Vonderg, D. B., British Medical fournal, 1974, 3, 137.

18 Catterall, M., and Vonderg, D. B., British Medical fournal, 1974, 3, 137.
19 Catterall, M., Hutton, I., and Burn, I., Proceedings of the Royal Society of Medinine, 1974, 67, 656.

\section{A Rose by Any Other Name}

Primary medical care-at one time seen by cynics as no more than general practice given a fancy name-is now beginning to acquire a clear identity, and one which is proving attractive to new medical graduates. ${ }^{1}$ The fundamental differences between primary care and traditional general practice are its use of a team of health professionals rather than the solitary figure of the family doctor and, as episodes of acute illness have become less prominent in domiciliary medicine, the priority given to prevention and supportive care.

It would, therefore, be wrong to see the primary health team simply as a means of stretching medical care by providing family doctors with a corps of ancillary workers. Its purpose is to enlarge the scope of primary care, so that it provides a more comprehensive health service rather than just a means of treating illness. This emerges very clearly from Primary Health Care Teams, ${ }^{2}$ a report published last week by the B.M.A. Board of Science and Education, which discusses the provision of health care in developed and developing countries. In Britain at least Professor A. D. Roy and his fellow-experts made two assumptions: that a general practitioner should be at the centre of the health team and that the trend will continue for general practitioners to form large groups and to work from health centres. Once large teams have been set up, they saw the emphasis as likely to continue to move towards preventive programmes-including both health education and screening for early disease-and towards rehabilitation and special clinics for the chronic diseases.

Formation of these primary health teams will have an effect on the shape of the hospital services, too, says the report. It recommends development of community hospitals, staffed by members of the primary health teams but able to call upon consultants for advice. Somewhat provocatively, perhaps, the report argues that the provision of general practitioner maternity units within community hospitals "would accelerate the disappearance of domiciliary midwifery, whereas a trend towards the district general hospital would be likely to result in women choosing to be delivered at home rather than make long or complex journeys to be confined." Another thoughtprovoking conclusion drawn by the panel is its suggestion that the comprehensive care provided by the primary care team should reduce demands on hospital accident and emergency departments, and should also make it possible to dispense with deputizing services.

Clearly if the amount of clinical work done by the primary team is to increase in this way and there is to be no great change in the number of doctors then some of the work done by doctors at present will have to be done by someone else. The future role of nurses in primary care is still far from agreed -and indeed the panel members took different views on the matter. No-one disputes that nurses' work should be tailored to their skills-and that means not wasting the time of a modern S.R.N. making beds. But should community nurses concentrate on their traditional role (in primary care) of preventive medicine or should it be enlarged to include curative medicine too? The panel suggests that it is practicable for nurses to assess patients and initiate therapy-though "only under the effective supervision of a medical practitioner and only in specialized and restricted areas in which they have acquired the appropriate knowledge and skill." One example of such an area within general practice might be family planning, as suggested by Dr. M. Smith and others in a letter this week (p. 161). A wider role for nurses is in line with the proposals made in the Briggs report ${ }^{3}$ for family nursing sisters trained in either clinical or preventive nursing in the community. Professor Roy and his colleagues acknowledge that there is a body of opinion which does not favour any recognition of nurses as competent to make independent decisions: they suggest that the conflict of views could be resolved by a controlled comparison of primary health care teams including nurses with others which did not.

Before rushing to make such comparisons, however, it would be well to remember that the quality of care provided for patients is influenced by other members of the primary care team-social workers, physiotherapists, pharmacists, dietitians, and drivers-and the staff who so often make the first contact, the receptionists. Professor Roy's report states that receptionists "should not be asked to make a clinical decision"-yet very often such decisions are implicit in arranging appointments. One of the main criticisms of current trends in general practice discussed in the Godber Report ${ }^{4}$ was the barrier that receptionists could erect between patients and their doctors. Sometimes health centres and large groups may seem more of a success to those working in them than to the communities they serve. In an era when consumers' voices are so influential, they should not be left out when traditional patterns of behaviour are abandoned, no matter how good the reasons.

\footnotetext{
1 British Medical fournal, 1974, 4, 50.

2 B.M.A. Board of Science and Education, Primary Health Care Teums, (Professor A. D. Roy, chairman). London, B.M.A., 1974.

${ }^{3}$ Report of the Committee on Nuring (Professor A. Briggs, chairman). London, H.M.S.O., 1972 .

4 General Medical Services, Report of the Joint Working Party (Sir George Godber, chairman). London, H.M.S.O., 1974.
} 